\title{
S-100B Concentration Is Not Related to Neurocognitive Performance in the First Month after Mild Traumatic Brain Injury.
}

Citation for published version (APA):

Stapert, S. Z., de Kruijk, J. R., Houx, P. J., Menheere, P. P. C. A., Twijnstra, A., \& Jolles, J. (2005). S$100 B$ Concentration Is Not Related to Neurocognitive Performance in the First Month after Mild Traumatic Brain Injury. European Neurology, 53(1), 22-26. https://doi.org/10.1159/000083678

Document status and date:

Published: 01/01/2005

DOI:

10.1159/000083678

Document Version:

Publisher's PDF, also known as Version of record

Please check the document version of this publication:

- A submitted manuscript is the version of the article upon submission and before peer-review. There can be important differences between the submitted version and the official published version of record.

People interested in the research are advised to contact the author for the final version of the publication, or visit the DOI to the publisher's website.

- The final author version and the galley proof are versions of the publication after peer review.

- The final published version features the final layout of the paper including the volume, issue and page numbers.

Link to publication

\footnotetext{
General rights rights.

- You may freely distribute the URL identifying the publication in the public portal. please follow below link for the End User Agreement:

www.umlib.nl/taverne-license

Take down policy

If you believe that this document breaches copyright please contact us at:

repository@maastrichtuniversity.nl

providing details and we will investigate your claim.
}

Copyright and moral rights for the publications made accessible in the public portal are retained by the authors and/or other copyright owners and it is a condition of accessing publications that users recognise and abide by the legal requirements associated with these

- Users may download and print one copy of any publication from the public portal for the purpose of private study or research.

- You may not further distribute the material or use it for any profit-making activity or commercial gain

If the publication is distributed under the terms of Article $25 \mathrm{fa}$ of the Dutch Copyright Act, indicated by the "Taverne" license above, 


\title{
S-100B Concentration Is Not Related to Neurocognitive Performance in the First Month after Mild Traumatic Brain Injury
}

\author{
Sven Stapert ${ }^{\mathrm{a}}$ Jelle de Kruijk ${ }^{\mathrm{b}}$ Peter Houx $^{\mathrm{a}}$ Paul Menheere $^{\mathrm{b}}$ \\ Albert Twijnstrab Jelle Jolles ${ }^{a}$ \\ ${ }^{a}$ Department of Psychology, Institute Brain \& Behaviour, Maastricht University, and \\ ${ }^{b}$ Department of Neurology, University Hospital, Maastricht, The Netherlands
}

\section{Key Words}

Mild traumatic brain injury $\cdot \mathrm{S}-100 \mathrm{~B} \cdot$ Neurocognitive performance

\begin{abstract}
The serum concentration of S-100B is reported to reflect the severity of brain damage. The purpose of this study was to determine whether elevated serum S-100B concentrations were related to neuropsychological test performance of patients in the subacute phase of recovery from mild traumatic brain injury (TBI). S-100B concentrations were measured in blood samples taken within $6 \mathrm{~h}$ after TBI. Serum S-100B was estimated using an immunoluminometric assay. Cognitive speed and memory were assessed with neuropsychological tests at a median of 13 days (range 7-21 days) after injury. The two groups, formed on a median split of initial serum S-100B concentrations ( $>$ or $<0.22 \mu \mathrm{g} / \mathrm{l}$ ) did not differ in age or education. The neuropsychological performance of the TBI patients was also compared with that of a healthy control group. Cognitive speed and memory performance of mild TBI patients were inferior compared to those of healthy subjects. There were no significant dif-
\end{abstract}

ferences within the TBI group when serum S-100B concentration was taken into consideration. The findings suggest that serum S-100B levels after mild TBI are not predictive of neuropsychological performance in the subacute stage of recovery.

Copyright $(2005$ S. Karger AG, Basel

\section{Introduction}

Although mild traumatic brain injury (TBI) is considered a benign neurological condition and is associated with uneventful recovery, many patients experience mild impairment of neurocognitive functioning in the first days to weeks after injury. Most experience completion of neuropsychological recovery in 1-3 months, although there is some variability in results [1]. However, a substantial number of patients (about 10-29\%) complain about long-term neuropsychological deficits. These patients are regarded to suffer from a persistent post-concussive syndrome $[2,3]$.

Reported risk factors for long-term neurobehavioral disorders include: underdiagnosis of initial injury severity [4], duration of post-traumatic amnesia and uncon-

\section{KARGER}

Fax +4161306 1234 E-Mail karger@karger.ch www.karger.com (c) 2005 S. Karger AG, Basel 0014-3022/05/0531-0022\$22.00/0

Accessible online at:

www.karger.com/ene
Sven Stapert, PhD

Department of Psychology, Maastricht University, PO Box 616

NL-6200 MD Maastricht (The Netherlands)

Tel. +31433881912, Fax +31433884125

E-Mail S.Stapert@psychology.unimaas.nl 
sciousness [5], age, sex, multiple mild TBIs [1], chronic pain [6], comorbid depression [7], psychosocial stressors, or misattribution of everyday symptoms [8]. In order to predict and prevent neuropsychological sequelae after mild TBI and possible development of a post-concussional syndrome, there is need for an early sensitive marker of brain damage in patients.

Serum levels of protein S-100B are reported to be increased after mild TBI $[9,10]$. This protein is synthesized in astroglial cells in all parts of CNS, so that high serum levels indicate damage to glial cells and blood-brain barrier dysfunction. Ingebrigtsen and colleagues [10, 11] showed that serum concentrations of S-100B measured early after head trauma provide information on diffuse brain damage and seem to be associated with neuropsychological outcome even in mild TBI. Little is known about the relation between serum S-100B and neuropsychological performance in the subacute stage of recovery. We do not know of any study relating S-100B concentrations to short- and long-term neuropsychological disorders in mild TBI patients only. Comparison of the predictive value of neurological status and neuron-specific enolase and S-100B concentrations showed the initial protein S-100B concentration (median: $27 \mathrm{~h}$ after trauma) to be the best predictor of long-term neuropsychological disorders in a heterogeneous cohort $[9,10]$. Patients with mildto-moderate TBI and neuropsychological deficits at 2 weeks post-injury had significantly higher serum levels of S-100B release than TBI patients without neuropsychological deficits.

The purpose of this study was to examine whether S100B levels as a marker of injury severity are associated with neuropsychological test performance in a sample of patients with mild uncomplicated TBI. We hypothesized that subjects who had increased serum S-100B levels would have a poorer cognitive function than subjects who had a less pronounced increase in serum S-100B levels.

\section{Method and Patients}

\section{Method}

Patients who arrived at the emergency department within $6 \mathrm{~h}$ of a trauma and who met criteria for mild TBI were asked to give their informed consent for taking blood samples for S-100B measurement. Blood samples were taken within $6 \mathrm{~h}$ after trauma and S-100B levels were measured using an immunoluminometric assay as described by de Kruijk et al. [12]. According to the study protocol, all patients were assessed neuropsychologically between 7 and 21 days after injury. Control subjects $(n=56)$ were recruited by means of advertisements placed in local newspapers and were paid for their participation. The advertisement stressed that par- ticipants should be healthy. Control participants were screened for the same exclusion criteria as the mild TBI patients and underwent the same procedure of neuropsychological evaluation as the patient group.

\section{Neuropsychological Assessment}

The choice of the fixed neuropsychological test battery was based upon earlier neuropsychological studies of mild TBI patients by Bohnen et al. [13] and Klein et al. [14]. These tests have proven sensitivity for detecting subtle neurocognitive impairment after mild TBI and a variety of subclinical neurological incidents [1418]. Cognitive speed was measured with two neuropsychological tests, the 40-item version of the Stroop test [19] (selective attention) and the Letter Digit Coding test [20] (processing speed). For data analysis we used the third Stroop card showing color words printed in ink of different colors. Memory was measured with the 15-word learning test, which tests immediate and delayed recall [21].

\section{Statistical Analysis}

Patients were divided into two groups based on a median split of their initial S-100B serum concentrations. We compared a group with low S-100B levels $(<0.23 \mu \mathrm{g} / \mathrm{l} ; \mathrm{n}=22)$ with a group with high $\mathrm{S}-100 \mathrm{~B}$ levels $(>0.22 \mu \mathrm{g} / \mathrm{l} ; \mathrm{n}=28)$. The range of S-100B concentrations in serum was $0.02-0.90 \mu \mathrm{g} / 1$.

Poor cognitive speed was defined as a score below the 10th percentile on both the Stroop test and the Letter Digit Coding test. Poor memory was defined as a score below the 10th percentile on both the immediate recall test and the delayed recall test. The neuropsychological scores were converted into percentile scores by using available norms from the Maastricht Aging Study [19]. Normative comparisons were corrected for age and education.

A one-way ANOVA was used to determine initial differences in injury characteristics and demographic variables between patient groups. To determine the effect of initial S-100B concentrations on cognitive performance, we used dichotomous endpoints, poor and good cognitive speed (Stroop and Letter Digit test) and poor and good memory (immediate and delayed recall on the word learning test). In these analyses we compared the cognitive function of mild TBI patients with high S-100B concentrations with that of patients with low S-100B concentrations. Odds ratios (OR) and 95\% confidence intervals (CI) were obtained by logistic regression analysis. A compound cognitive score was also constructed for cognitive speed and memory for additional analysis. We computed two compound scores based on dependent variables after transformation to standard scores using normative data from the Maastricht aging study: cognitive speed Z(third Stroop card + Letter Digit coding) $/ 2$ and memory Z(immediate recall + delayed recall) $/ 2$. We compared the cognitive performance of the two groups of TBI patients (high versus low serum S-100B concentration) using a one-way ANOVA.

Patients

Consecutive patients $(n=50)$ who visited the emergency department of the University Hospital Maastricht with an uncomplicated TBI were screened for inclusion in the study. Patients were included if they met clinical criteria for mild TBI: (1) a blunt blow to the head resulting in post-traumatic amnesia not exceeding $1 \mathrm{~h}$; (2) feeling dazed or initial loss of consciousness of $<15 \mathrm{~min}$; (3) Glasgow Coma Scale score of $14-15$ on presentation at the emergency department and (4) absence of focal neurological deficits. These criteria fell within the limits proposed by the American Congress of 
Table 1. Descriptive statistics for the three groups

\begin{tabular}{|c|c|c|c|c|c|c|}
\hline \multirow[t]{3}{*}{ Dependent variables } & \multicolumn{4}{|c|}{ Serum S-100B } & \multirow{2}{*}{\multicolumn{2}{|c|}{$\begin{array}{l}\text { Control subjects } \\
(\mathrm{n}=56)\end{array}$}} \\
\hline & \multicolumn{2}{|c|}{$<0.23(\mathrm{n}=22)$} & \multicolumn{2}{|c|}{$>0.22(\mathrm{n}=28)$} & & \\
\hline & mean & SD & mean & $\mathrm{SD}$ & mean & SD \\
\hline Immediate recall & 26.5 & 5.4 & 28.6 & 7.1 & 31.5 & 5.7 \\
\hline Delayed recall & 9.4 & 2.9 & 10.3 & 3.6 & 11.0 & 2.6 \\
\hline Stroop test & 42.7 & 12.3 & 38.3 & 7.8 & 38.1 & 11.2 \\
\hline Letter digit coding & 33.2 & 7.3 & 34.5 & 7.7 & 38.4 & 6.8 \\
\hline
\end{tabular}

See Method section for explanation of dependent variables.
Table 2. Percentage of subjects with poor cognitive speed or poor memory performance for each group

\begin{tabular}{llll}
\hline Dependent variables & Serum S-100B & $\begin{array}{l}\text { Control subjects } \\
(\mathrm{n}=56)\end{array}$ \\
\cline { 2 - 3 } & $<0.23(\mathrm{n}=22)$ & $>0.22(\mathrm{n}=28)$ & 2 \\
\hline Poor cognitive speed & 14 & 7 & 2 \\
Poor memory & 9 & 14 & 4 \\
\hline
\end{tabular}

See Method section for definitions of poor cognitive speed and poor memory.
Rehabilitation Medicine [22]. We chose to use these more conservative criteria to select a homogenous sample of mild TBI patients who fall at the 'mildest' end of the TBI spectrum.

Patients with previous head injuries, surgical conditions, alcohol or substance abuse, and patients with major psychiatric, neurological, medical problems or severe extracranial injuries (fractures, burns) were excluded. Patients with evidence of secondary intracranial complications were also excluded.

To detect intracranial complications in the first $24 \mathrm{~h}$ following the injury, 'home observation instructions' were given to a responsible person accompanying the patient. If a participant sustained significant injury in the interval between S-100B measurement and neuropsychological assessment, he or she was excluded from data analysis. Estimates of the duration of post-traumatic amnesia and of loss of consciousness were based on the information provided by patient and witnesses.

On average, patients $(\mathrm{n}=37)$ lost consciousness for $3.2 \mathrm{~min}$ $(\mathrm{SD}=4.1$; range $0-15 \mathrm{~min})$ and post-traumatic amnesia $(\mathrm{n}=50)$ lasted $18.9 \mathrm{~min}(\mathrm{SD}=19.0$; range $1-60 \mathrm{~min})$. At presentation the Glasgow coma scores of all patients were higher than 13 . Only 4 patients had scores of 14 . There were no significant differences between patient groups based on high versus low serum S-100B levels in the duration of unconsciousness, $\mathrm{F}(1,48)=1.215, \mathrm{p}<0.28$, or post-traumatic amnesia, $\mathrm{F}(1,48)=0.036, \mathrm{p}<0.90$. Twenty-three patients $(n=50)$ were female $(46 \%)$.

The average age of the total sample $(n=106)$ was 35.2 years $(\mathrm{SD}=15.9)$, and the average education was 12.9 years $(\mathrm{SD}=3.4)$. No significant differences were found between groups in age, $\mathrm{F}(2,103)=1.043, \mathrm{p}<0.40$, or years of education, $\mathrm{F}(2,103), 1.781$, $\mathrm{p}<0.20$.

\section{Results}

No mild TBI patients were excluded from data analysis, because of secondary intracranial complications. At a median of 13 days after injury (range 7-24 days) neuropsychological assessment was completed. Every patient was neurologically examined before neuropsychological screening. No abnormalities that could compromise neuropsychological testing were found.

We calculated the probability that poor cognitive function depended on the serum S-100B concentration. Elevated serum S-100B level did not increase the risk of poor cognitive speed (OR $0.5,95 \%$ CI $0.1-3.2$ ) or poor memory performance (OR $1.7,95 \%$ CI $0.3-10.1)$ (tables 1,2 ). Nine percent of the patients with low S-100B levels and $14 \%$ of the patients with high S-100B levels had an impaired memory performance. Cognitive speed was impaired in $7 \%$ of the patients with high S-100B levels and in $14 \%$ of the patients with low S-100B levels. Parametric comparisons of extreme groups, based on S-100B concentrations, did not reveal differences in cognitive performance (data not shown). Compound scores for cognitive speed and memory also did not reveal any differences in performance between the two TBI groups: cognitive speed $(F(1,48)=0.338, p<0.60)$ and memory $(F(1,48)=0.903$, $\mathrm{p}<0.40)$. We found low and non-significant correlations 
between injury severity variables and S-100B concentrations $(\mathrm{r}<0.20$, n.s.) and cognitive performance and S100B concentrations $(r<0.16$, n.s. $)$.

We also calculated the probability that mild TBI resulted in poor cognitive function (yes/no). Memory performance was impaired in $12 \%$ of mild-TBI patients but in only $4 \%$ of the controls (OR 3.7; 95\% CI 0.7-19.2). Cognitive speed was impaired in $10 \%$ of mild TBI patients compared to $2 \%$ in the controls (OR $6.1 ; 95 \%$ CI $0.7-54.2)$.

\section{Discussion}

There is still no biological marker to predict continuing neuropsychological symptoms after mild TBI. Detecting patients at risk of developing post-concussional symptoms is of potential interest, because neurobehavioral rehabilitation can reduce the risk of persistent symptoms [23]. In this study we focused on acute serum levels of protein S-100B as a marker for brain damage after mild TBI in relation to neurocognitive performance.

Cognitive speed and memory function were not different in patients with or without high serum levels of protein S-100B, but were worse than those of healthy subjects. These results suggest that an elevated serum S-100B level is not predictive of neuropsychological performance during recovery from mild TBI. Although neuropsychological decrements are common in this population, it is notable that the majority of mild TBI patients did not have unusually low scores on cognitive measures for speed and memory.

However, other studies with mild TBI patients have used different cut-off values for serum S-100B levels (0.2$0.5 \mu \mathrm{g} / \mathrm{l})[10,24]$ and thus it is possible that higher con- centrations of serum S-100B than those found in this study are associated with poorer subacute neurocognitive performance.

Blood samples were drawn within $6 \mathrm{~h}$ after injury. It is presently not known whether this is the right time frame to accurately measure the concentration of S-100B levels. There is still no consensus in the literature on the dynamics of S-100B after TBI, although there is some indication that levels of S-100B tend to fall rapidly after release following severe TBI [25]. A variety of studies using different outcome variables have chosen different intervals between injury (or surgery) and collection of serum S-100B (1-48 h) [9, 25-27].

We chose 1-3 weeks after injury for neuropsychological assessment, because it is well known that pain, anxiety and stress have a significant influence on neuropsychological performance $[1,2]$. These are common symptoms following a mild TBI but tend to resolve within days after injury. Possible influences of these symptoms on neurocognitive performance are minimized in this way.

Although we used a short cognitive battery that has proven to be sensitive for detecting subtle neurocognitive impairment after mild TBI [3], it could be that a more extensive neuropsychological battery is more sensitive in demonstrating mild neurocognitive deficits. Herrmann et al. [9] used a more extensive battery, but found mostly disorders of attentional performance, executive functions, interference susceptibility, reduced error control, and memory performance. These cognitive domains are covered by our cognitive screening battery.

This study suggests that blood levels of S-100B do not reflect cognitive dysfunction after mild TBI. However, it is possible that our results would have been different if the blood samples had been taken at a different time.

\section{References}

- 1 Binder LM: A review of mild head trauma. II. Clinical implications. J Clin Exp Neuropsychol 1997; 19:432-457.

- 2 Alexander MP: Mild traumatic brain injury: Pathophysiology, natural history, and clinical management. Neurology 1995;45:1253-1260.

- 3 Bohnen N, Twijnstra A, Jolles J: Persistence of postconcussional symptoms in uncomplicated, mildly head-injured patients: A prospective cohort study. Neuropsychiatry Neuropsychol Behav Neurol 1993;6:193-200.

- 4 Alexander MP: In the pursuit of proof of brain damage after whiplash injury. Neurology 1998; 51:336-340.
5 Iverson GL, Lovell MR, Smith SS: Does brief loss of consciousness affect cognitive functioning after mild head injury? Arch Clin Neuropsychol 2000;15:643-648.

6 Iverson GL, McCracken LM: 'Postconcussive' symptoms in persons with chronic pain. Brain Inj 1997;11:783-790.

7 Busch CR, Alpern HP: Depression after mild traumatic brain injury: A review of current research. Neuropsychol Rev 1998;8:95-108.

8 Bernstein DM: Recovery from mild head injury. Brain Inj 1999;13:151-172.
9 Herrmann M, Curio N, Jost S, Grubich C, Ebert AD, Fork ML, Synowitz H: Release of biochemical markers of damage to neuronal and glial brain tissue is associated with short- and long-term neuropsychological outcome after traumatic brain injury. J Neurol Neurosurg Psychiatry 2001;70:95-100.

10 Waterloo K, Ingebrigtsen T, Romner B: Neuropsychological function in patients with increased serum levels of protein S-100 after minor head injury. Acta Neurochir (Wien) 1997; 139:26-32. 
-11 Ingebrigtsen T, Romner B: Management of minor head injuries in hospitals in Norway. Acta Neurol Scand 1997;95:51-55.

-12 De Kruijk JR, Leffers P, Menheere PP, Meerhoff S, Twijnstra A: S-100B and neuron-specific enolase in serum of mild traumatic brain injury patients. A comparison with health controls. Acta Neurol Scand 2001;103:175-179.

13 Bohnen N, Twijnstra A, Jolles J: Post-traumatic and emotional symptoms in different subgroups of patients with mild head injury. Brain Inj 1992;6:481-487.

$>14$ Klein M, Houx PJ, Jolles J: Long-term persisting cognitive sequelae of traumatic brain injury and the effect of age. J Nerv Ment Dis 1996;184:459-467.

15 Bosma H, van Boxtel MP, Ponds RW, Houx PJ, Jolles J: Pesticide exposure and risk of mild cognitive dysfunction. Lancet 2000;356:912913.

16 Houx PJ, Vreeling FW, Jolles J: Age-associated cognitive decline is related to biological life events; in Iqbal K, Winblad B, Nishimura T, Takeda M, Wisniewski HM (eds): Alzheimer's Disease: Basic Mechanisms, Diagnosis, and Therapeutic Strategies. Chichester, Wiley, 1991, pp 353-358.
17 Moller JT, Cluitmans P, Rasmussen LS, Houx P, Rasmussen H, Canet J, Rabbitt P, Jolles J, Larsen K, Hanning CD, Langeron O, Johnson T, Lauven PM, Kristensen PA, Biedler A, van Beem H, Fraidakis O, Silverstein JH, Beneken JE, Gravenstein JS: Long-term postoperative cognitive dysfunction in the elderly ISPOCD1 study. ISPOCD investigators. International Study of Post-Operative Cognitive Dysfunction. Lancet 1998;351:857-861.

18 Van Exel E, Gussekloo J, de Craen AJ, Bootsma-van der Wiel A, Houx P, Knook DL, Westendorp RG: Cognitive function in the oldest old: Women perform better than men. J Neurol Neurosurg Psychiatry 2001;71:29-32.

19 Klein M, Ponds RW, Houx PJ, Jolles J: Effect of test duration on age-related differences in Stroop interference. J Clin Exp Neuropsychol 1997; 19:77-82.

20 Lezak MD: Neuropsychological Assessment, ed 3. New York, Oxford University Press, 1995.

21 Brand N, Jolles J: Learning and retrieval rate of words presented auditorily and visually. $\mathrm{J}$ Gen Psychol 1985;112:201-210.
22 ACRM: Definition of mild traumatic brain injury. J Head Trauma Rehabil 1993;8:86-87.

23 Mittenberg W, Tremont G, Zielinski RE, Fichera S, Rayls KR: Cognitive-behavioral prevention of postconcussion syndrome. Arch Clin Neuropsychol 1996;11:139-145.

24 Ingebrigtsen T, Romner B, Marup-Jensen S, Dons M, Lundqvist C, Bellner J, Alling C, Borgesen SE: The clinical value of serum S-100 protein measurements in minor head injury: A Scandinavian multicentre study. Brain Inj 2000; 14:1047-1055.

25 Jackson RG, Samra GS, Radcliffe J, Clark GH, Price CP: The early fall in levels of S-100B in traumatic brain injury. Clin Chem Lab Med 2000;38:1165-1167.

26 Biberthaler P, Mussack T, Wiedemann E, Kanz KG, Koelsch M, Gippner-Steppert C, Jochum M: Evaluation of S-100B as a specific marker for neuronal damage due to minor head trauma. World J Surg 2001;25:93-97.

27 Rasmussen LS, Christiansen M, Hansen PB, Moller JT: Do blood levels of neuron-specific enolase and S-100 protein reflect cognitive dysfunction after coronary artery bypass? Acta Anaesthesiol Scand 1999;43:495-500. 